\title{
FIRST RECORD OF CHORDODES CREPLIN, 1847 (NEMATOMORPHA, GORDIOIDEA) SPECIES FROM A HILLSTREAM OF BANDARBAN, BANGLADESH
}

M. Niamul Naser*1, Mostafa Ali Reza Hossain², M. Ali Azadi³, M. Golam Quader Khan $^{1}$, M. Arshad-Ul-Alam ${ }^{4}$ and Selina Sultana

\section{Updating Red List Bangladesh Project, International Union for Conservation of} Nature (IUCN), Country Office Dhaka, Bangladesh

One Sutanoli Shap (local name) was caught from a freshwater hill-stream known as Shaila Propat at Bandarban (location $22^{\circ} 09^{\prime} 02.31^{\prime} \mathrm{N}$ and $92^{\circ} 13^{\prime} 00.28^{\prime}$ E) on $12^{\text {th }}$ November 2014 during an exploration survey by IUCN team. The habitat is shown in Plate 1.

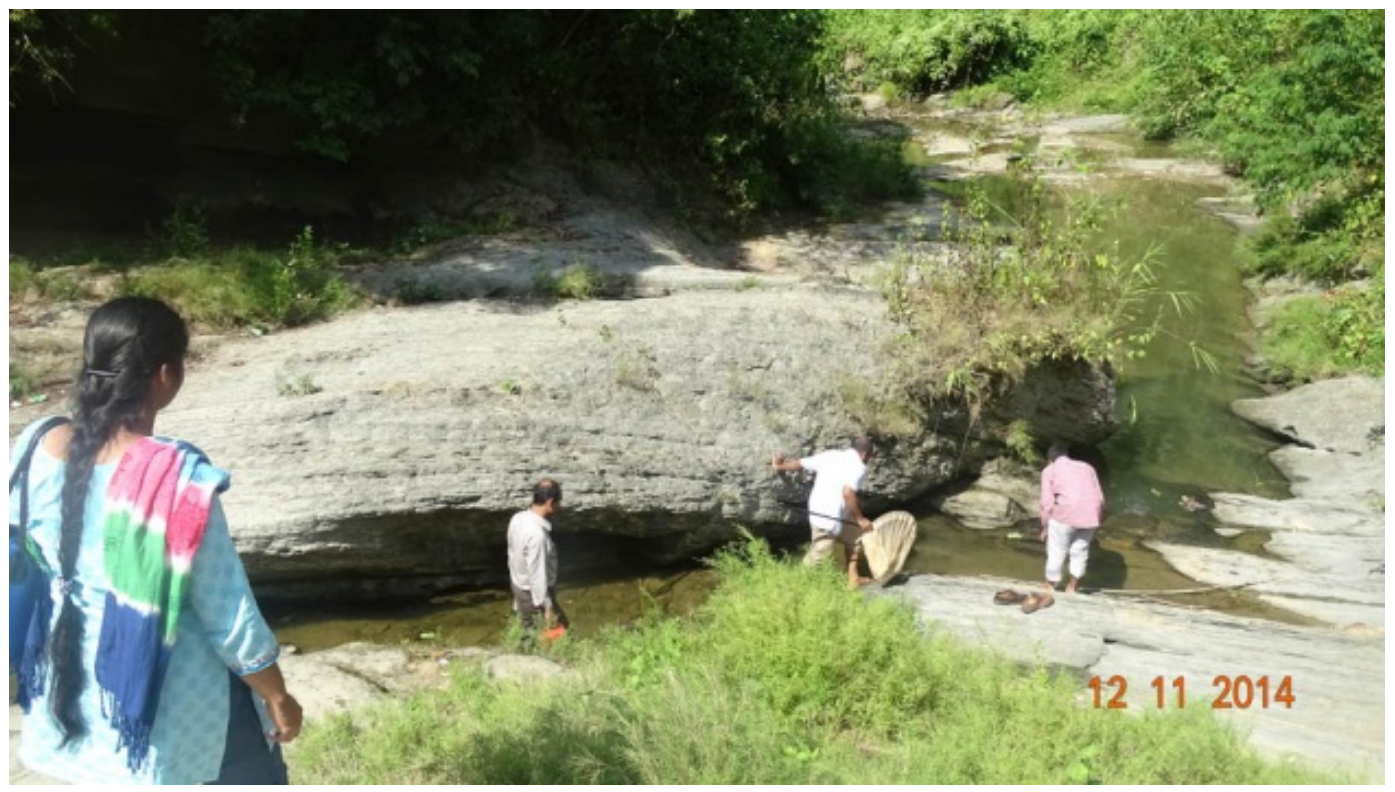

Plate. 1. Habitat of the collected Chordodes Nematomproha at Shaila Propat hill-stream at Bandarban

\footnotetext{
"Corresponding author: mnnaser@du.ac.bd; 1Department of Zoology, Faculty of Biological Sciences, University of Dhaka, Dhaka, Bangladesh; ${ }^{2}$ Department of Fisheries Biology and Genetics, Faculty of Fisheries, Bangladesh Agricultural University, Mymensingh, Bangladesh; 3Department of Zoology, Faculty of Biological Sciences, University of Chittagong, Chittagong, Bangladesh; ${ }^{4}$ Department of Zoology, Bandarban Government College, Bandarban Hill District, Bangladesh.
} 
The collected sample is preserved in the museum of the Department of Zoology, University of Dhaka, Dhaka, Bangladesh. We have identified it as one of the Phylum Nematomorpha species for the first time record from Bangladesh geographical area. The worm is often referred to as "horsehair worms" as they are very long and thin without a distinct head (Storer et al. 1979). Until the late 1800 's it was believed that these worms were shed into the water from horse's manes and tails (Hickman 1973, Barnes 1980). The collected Nematomorphs is 31.5 centimeters in length and 0.493 gram of weight (Plate 2). It lacks a distinct head, but possesses a thick iridescent white cuticle. In live condition, it was very active and performing its locomotion by whipping like undulations.

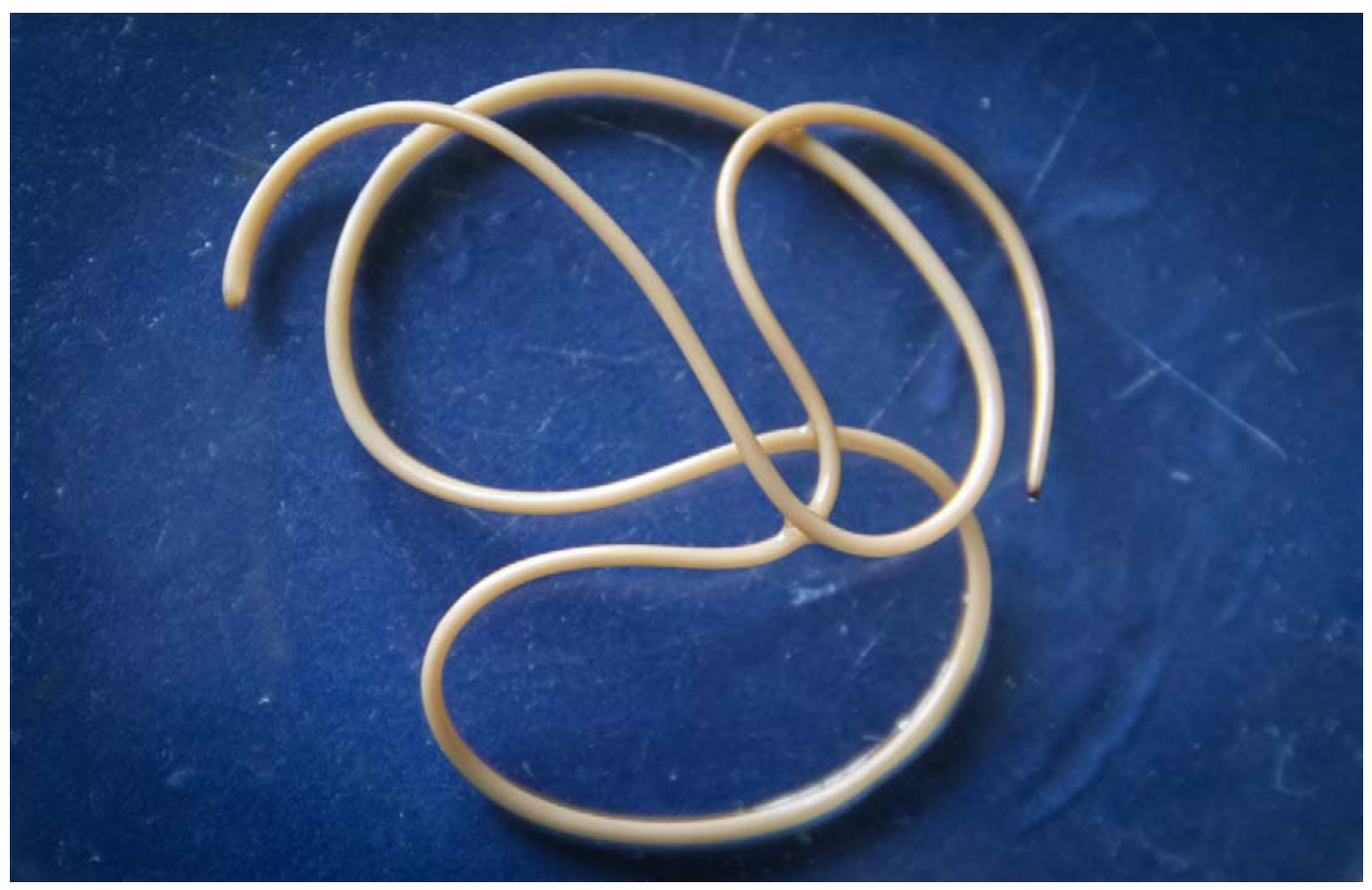

Plate 2. Adult free living Horsehair worm, Chordodes Creplin, 1847 (Nematomorpha: Gordioidea) collected at Shaila Propat hill-stream at Bandarban.

We also confirm from the morphological features that the genus is an adult form of Chordodes Creplin, 1847 under the Family Chordodidae and order Gordioidea. Seventeen species of freshwater Nematomorpha have been reported from India of which seven belongs to the genus Chordodes (Schmidt-Rhaesa and Lalramliana 2011, Schmidt-Rhaesa and Yadav 2013). We believe the collected speciemen belongs to one of the species from the reported genus as species identification needs to be done by scanning electron microscopy. 
From literature, it is noted that the adult worms are free living, but that the larval forms are parasitic to Arthropod host, such as orthopterans, mantids, beetles, cockroaches and crustaceans (Schmidt-Rhaesa and Ehrmann 2001, Hanelt et al. 2005). About 351 freshwater species are known (Zhang 2011) and a conservative estimate suggests that there may be about 2000 freshwater species worldwide (Poinar Jr. 2008). It is not known from the present habitat about the larvae and their hosts. It is also unknown for how long the preparasitic forms can encyst before they exhaust their metabolic reserves and die (Hanelt et al. 2005).

Acknowledgements: We thank to the 'IUCN Updating Red List Bangladesh Project' (funded by World Bank and led by the Department of Forest, MoEF, GoB) to support the expedition to the Hilly area of Bangladesh by the Crustacean group. We also thank Mr S.M. Ifta Khairul Alam for taking the photographs of the specimen.

\section{LITERATURE CITED}

BARNES, R.D. 1980. Invertebrate Zoology. Saunders College/Holt, Rinehart and Wilson, Philadelphia.

HANELT, B, THOMAS, F. and SCHMIDT-RHAESA, A.2005.Biology of the phylum Nematomorpha. Advances in Parasitology 59: 244-305.

HICKMAN, C.P. 1973. Biology of the Invertebrates. The C. V. Mosby Company. Saint Louis.

PONINAR Jr., G (2008). Global diversity of hairworms (Nematomorpha: Gordiaceae) in freshwater. Hydrobiologia 595(1): 79-83.

SCHMIDT-RHAESA, A. and EHRMANN, R. 2001. Horsehair worms (Nematomorpha) as parasites of praying mantids with discussion of their life cycles. Zool. Anz. 240: 167-179.

SCHMIDT-RHAESA, A. and LALRAMLIANA. 2011. Chordodes mizoramensis (Nematomorpha, Gordiida), a new species of horsehair worm from Mizoram, NorthEast India. Zoo Keys 75: 1-8.

SCHMIDT-RHAESA, A. and YADAV, A.K., 2013. One new species and a new record of the genus Chordodes (Nematomorpha: Gordiida) from North-East India. Zootaxa 3693(2): 293-300.

STORER, T.I., USINGER, R.L., STEBBINS, R.C. and NYBAKKEN, J.W. 1979. General Zoology. 6th Edn. McGraw-Hill Book Company. New York .

ZHANG, Z.Q. 2011.Animal biodiversity: An introduction to higher-level classification and taxonomic richness. Zootaxa 3148: 7-12. 